\title{
CONCEPTUAL METAPHOR RELATED TO EMOTION
}

\author{
Cecep Agus \\ Faculty of Letters Universitas Padjadjaran \\ Adresse: Jln. Dipati Ukur No.32 Bandung \\ Email: cecepagus@yahoo.co.id
}

\begin{abstract}
Abstrak
Metafora Konseptual yang berkaitan dengan Emosi. Penelitian ini bertujuan untuk mengkaji apakah terdapat konsep metafora yang terjadi dalam bahasa Inggris yang mewakili emosi secara keseluruhan pada British National Corpus (BNC). Penelitian ini menganalisis tanda-tanda yang digunakan orang untuk mengekspresikan emosi, menelisik fungsi sosial dan budaya secara emosional di seluruh dunia. Penelitian ini, lebih jauh lagi, dilakukan untuk menemukan aturan konseptualisasi emosi dan konsep abstrak yang membantu orang memahami beberapa aspek yang sulit, memberi warna, dan megembangkannya. Metode yang digunakan dalam penelitian ini yaitu metode deskriptif kualitatif mengikuti Causation Concepts dan Force Dynamics principle. Metode analisis digunakan untuk menemukan beberapa metafora konseptual yang berasal dari ekspresi linguistik metafora di mana mereka muncul sebagai fenomena linguistik alami dalam cara pandang dan konsep emosi manusia. Data tersebut dalam bentuk wacana tertulis dikutip dari BNC. Hasil penelitian menunjukkan bahwaterdapat beberapa metafora konseptual di dalamnya. Studi ini menunjukkan bahwa kegiatan berbicara, merasakan, berpikir, dan mengidentifikasi merupakan suatu proses yang saling berkaitan dan menunjukkan bagaimana emosi seperti kebahagiaan, kesedihan, kemarahan dan rasa cinta melekat pada bahasa. Secara formal dan fungsional, konsep metafora muncul bersamaan dengan proses pemikiran manusia, dan sebagian besar tidak disadari. Hal ini merupakan struktur dasar dari penalaran bahwa pikiran digunakan untuk memahami aspek abstrak yang rumit.
\end{abstract}

Kata kunci: Konsep , metafora konseptual , emosi , ekspresi linguistik metafora

\begin{abstract}
Conseptual Metaphor related to Emotion. This study investigates whether there are conceptual metaphors occuring in English representing emotion as a whole in British National Corpus (BNC). It analyzes the signals people use to express emotion, looking at the social and cultural functions of emotional language around the world. This study, furthermore, has an arrangement to find the rule of conceptualizing emotion and abstract concept which helps people grasp some difficult aspect, give colour, and make it move.The method used in this study is descriptive qualitative following the Causation Concepts and Force Dynamics principle. The method of analysis is to locate some conceptual metaphors deriving from metaphorical linguistic expressions where they appeared as natural linguistic phenomenon in the way people view and conceptualize the emotion. The data are in the form of written discourse cited from BNC. Results show that there are some conceptual metaphors in it. The study demonstrates that speaking, feeling, reflecting, and identifying are interrelated processes and shows how emotions such as happiness, sadness, anger and love are attached to language. Formally and functionally,
\end{abstract}


the conceptual metaphors come out with the human thought processes, and are largely unconscious. It is a fundamental structure of reasoning that the mind utilizes to make sense of more complicated abstract aspect.

Keywords: Concept, conceptual metaphor, emotion, metaphorical linguistic expressions

\section{INTRODUCTION}

Language is a means we use to communicate feelings; we also reflect emotionally on the language we and others use. Emotion is inherently very helpful to a greater extent of human life. Every dimension of every language at least potentially encodes emotion. Emotions can help us in some segments of the world such as in our daily life, in science, and in the art world. In line with this aspect, Goodman has indicated implicitly that in daily life, classification by feeling is often of greater importance than classification by other properties. He says that "We are likely to be better off if we are skilled in fearing, wanting, braving or distrusting the right things, animate or inanimate, than if we perceive only their shapes, sizes, weight, etc." (Goodman, 1976:251). We have free will concerning our emotions. We can be masters ouf our emotions

Emotion is a means of language people use to communicate with others. Any attempt to understand the nature of language must try to describe and explain the way in which emotion conceptualized. In this respect, the interrelated significance between emotion and language meaning is highlighted by Snaevar (1997: 284) as he states that emotions are shot through with meaning, making them virtual symbolic structures and by virtue of being such structures it makes sense to say that they can represent segments of reality.

Regarding the persuading significance of emotion in which it is an adjunct to language, it is worth our attention that the way in which people convey and view their experience of the world are influenced by emotion. In this respect, Sartre (in Snaevar, 1997: 341) highlights that emotion is a transformation of the world. It transforms an object just like metaphors do. To illustrate, people can experience an object such as frightful, saddening, irritating, and suchlike based on a total transformation of the world. As a result, such a transformation has a metaphorically magical nature.

The transformation of the world which is established by emotion leads to the shaping of one's point of view. Let us take the case of when people see everything in an emotional manner, they will not see the world as a natural law as it is; on the contrary, they see it a magical object. For instance, in a joyful circumstance, they sing and dance just like as music star; on the other hand, in fear, they act as though they use magical instruments to make fearful things disappear from their lives. Summing up, emotion affecting in the way they act, communicate with others, and convey their experience of the word have the basis in "aspect-seeing" (Snaevar, 1997: 5)

In line with the fact that emotion transforms its object, it can therefore be recognized that emotions and metaphors have much in common. In the process they have similarity to transform their objects and make certain features of these objects salient. In this respect, de Sousa makes it clear that emotions are one of the mechanisms we use to make features of reality salient (de Sousa, 1987: xv). Thus, the transformation of perceived features of a circumstance caused by the fear makes those features salient.

In addition to the similar process, emotions and metaphors have the similarity in structure. In this case, a Hungarian linguist, Kövecses, has drawn attention to 
the fact that emotions have a metaphoric structure (Kövecses, 2010). On the other hand, Lakoff and Johnson have expressed a similar view that ways of viewing events, activities, emotions, ideas, etc., are conceptualized as entities and substances which give rise to metaphors. They maintain that the sources of emotional metaphors tend to be bodily experiences.

Linguistic studies have shown that metaphorsare so abundant in people's daily language as soon as such complex and intricate ideas are being discussed, researched, and philosophized about. They reflect underlying metaphorical thought: "Metaphors as linguistic expressions are possible precisely because there are metaphors in a person's conceptual system" (Lakoff and Johnson 1980:6). The most important find is that metaphors are not only devices that rhetoricians and poets pick and choose among to spice up and ornament their arguments and verses, but are fundamental structures of reasoning that the mind utilizes in order to make sense of the more complicated aspects of people's existence. Consequently "human thought processes are largely metaphorical" (Lakoff and Johnson 1980:6).

Current developments in metaphor give a great interest to conduct research as one realization of semantic concerns. Therefore, studies directed to conduct research on British National Corpus (BNC) regardingthe urgency of revealing the conceptual metaphors which might leads in difficulties in apprehending the leading ideas. Additionally, it reveals many groundbreaking and exciting facts about how the human mind makes use of metaphors. Some questions, thus, are proposed to pursue the answers of the research problems: (1) What conceptual metaphors are used in expressing emotion; (2) What semantic features indicate the relation between conceptual metaphor and emotion.

\section{METHOD}

The method of analysis is to locate some conceptual metaphors deriving from metaphorical linguistic expressions where they appeared as a natural linguistic phenomenon in the way people view and conceptualize the world. The method therefore applied in this research is descriptive. As Bogdan and Biklen have perceptively indicated that qualitative research is descriptive and the data collected arein the form of words rather than numbers (in Sugiyono, 2009: 9).

The primary basic idea behind this technique is fairly straightforward. The data of this research are analyzed concerning the lexical unit in the text to establish general understanding of the meaning, thenmetaphorical use is checked by making clear that the text is defective when it seems to violate rules of conversation or otherwise make no sense in context. The next step is picking up the lexical item referring to the source and target domain of conceptual metaphors under investigation.

In this study, the writer then identifies all metaphorical expressions that the search word is a part of and group them into coherent groups representing general mappings. This general approach identified in this way represents the complete inventory of metaphorical mappings occurring in the target domain in question. Most of the data the writer uses are metaphorical expressions associated with the target domain of mostly basic emotions, namely, as a test case, the words love, anger, fear, happy, and sadness.

\section{RESULTS AND DISCUSSION}

The finding from the metaphor research - the conceptualization of emotionwill be presented and discussed. There are 
sixty-five expressions deriving from BNC taken as the data in this research. However, not every metaphor found in the corpus will be presented and discussed. In order to focus on a more in-depth and qualitative discussion of emotion metaphors and underlying structures of conceptual metaphors, the data of this researchwill be focused on those that are most interesting and the most representative. In this case, the writer applies the key concept of causation - that of causation as a physical force to indicate its metaphorical constitution, and Force Dynamics as the work of Johnson (in Gibbs, ed., 2008:40). The underlying metaphorical structure of this concept is by performing analyses on semantics of causal terms which render the metaphorical nature of this concept more evident. For this reason, this study of causal concept is coming from the way of people conceptualize an event generally.

\section{The Concept of Causation}

The concept of causation is the concept in which people customarily conceive an event that comprises causation as a physical force to indicate its metaphorical constitution. This concept is established by performing analyses on the semantics of causal terms, which make the metaphorical nature of this concept appear more evident. This concept comprises the Location Event-Structure Metaphor, the Object Event-Structure Metaphor, and the Causal Path Metaphor.

The metaphors used when the corpora discuss emotion and their relation make for an interesting study, and these metaphorical structures are just as central to the emotion concept as the actual issues, thus deserving a closer investigation.

\section{The Location Event-Structure Metaphor}

The location event-structure
metaphor comprising mainly some prominent conceptual metaphors involved an understanding of change of state as motion from one location to another location. The detailed structure of mapping which is given illustrates the semantics of the terms for events. Based on the findings, there are eight expressions considered as emotion metaphor at the location eventstructure. We tearfully put the word regret

We are now introduced to the common concept of emotion metaphor that will be important in reasoning. In this expression, the use of put makes sense if we are relying on conceptual metaphors that see the emotion as a physical mass. In this context, it can be seen the physical action of put being applied in a metaphorical manner to the abstract concept of emotion, which is quite familiar in our ordinary way.

The semantics of put can be defined as a sort of action that places or positions an object, or leaves something at a particular place. Additionally, it is a physical action to be in or move into a horizontal or vertical position on a surface.

Given this evidence, the writer thus argues that the expression in this data has brought about metaphorical shift. Because of the availability of the conceptual metaphor used in this expression, there may be grounds to argue that there are thought processes involved where abstract concept of emotion is mapped onto the physical attribute. To illustrate, if something has the potentiality to be situated at a particular place, it surely needs a physical mass; conversely, something that is abstract and thus does not have a physical manifestation would not be placed on a surface horizontally or vertically. In other words, an abstract concept couldnot have a position in, more specifically, a certain concrete place. 
This metaphor is much used by those who are mostly in contrition using metaphoric images, making it reasonable to suggest that it not only is a linguistic metaphor, but a conceptual metaphor as well, in which we conceptualize the emotion in term of inanimate objects. Following this, the expression in this data can be said to be some sort of explicit realization of the causation concept - that of causation as a physical force, and the writer sees that the whole of the emotion rendition in this context could be explained as being in line with CHANGE OF STATE IS MOVEMENT FROM ONE LOCATION TO ANOTHER conceptual metaphor.

Let us now look over the working of the most basic and skeletal emotion scenario in the theory of causation concept. We will see what is exactly carried over to the concept of emotion when this linguistic expression is extended into the causation concept in general. In the source domain of physical forces and motions, to "put" something to someplace is applying continuous force to position or situate the object. Consequently, such an action causes the object to move away from one location of person's possession to another. When metaphorically transformed into the causation of metaphorical concept in general, the semantics of put thus entails continuous force application to come out with the change of state. Therefore, "We tearfully put the word regret" entails the constant physical power until it arrives at the metaphorical—change of state.

Based on that mapping, the evidence seems to be strong that there is the consistency of this linguistic metaphor and systematically linked source with target domain, the writer therefore argues that there is an underlying conceptual metaphor that gives rise to the linguistic metaphorical expression above. Particularly, the writer could view this data as linguistic instance of the location event-structure metaphor

\section{The Object Event-Structure Metaphor}

This metaphorical structure of conceptual metaphor is a second major metaphor system for certain types of causation. This structure mainly concerns the one that conceives of change of state or has an attribute or property as the acquisition of possession. Based on the findings, there are seven expressions considered as emotion metaphor at the Object Event-Structure. The data will be analyzed based on the findings as the following:

Happiness is what we are looking for

People often use this conventionalized linguistic expression that indicates any of the metaphorical entailments in talking about happiness. That we are dealing with conceptual metaphors can be further sustained by the use of looking for in the expression above in which physical actions of searching aspect used for envisaging this concept of emotion have been extended.

The semantics of look for is literally defined as an action that is intended to find out the often hidden thing. Equally, it is an action to look somewhere carefully in order to find lost properties. Based on these features, the writer can suggest that the phrase has gone through a metaphorical shift. In the case of happiness, the writer argues that to look for has to be metaphorical since happiness is takenas an abstract nature, and that we have to conceptualize happiness as an object before we could look for it.

The evidence seems to be strong that happiness is here seen as the sum of all committed acts of happiness in this world. Happiness thus becomes a separate and independent entity which might then be obtained using some effort. At this point, we 
saw that conceptualizing happiness using the term such as looking for, searching, etc., makes it easier to reason and talk about such concepts. On the whole, happiness is mapped as a desired object. Simultaneously, the entailment potential given above is exploited by the conceptual metaphor A PURPOSE IS DESIRED OBJECT.

Let us now examine the most basic and skeletal emotion scenario in the theory of causation concept, that is, causation as a physical force. To illustrate, in the source domain of desired object, to "look for" something or someone is applying a serious ceaseless effort to discover, especially where a thing or person is, or to discover where to obtain or how to achieve something. Accordingly, it specifies a way of acquiring a desired object such as happiness, which equates metaphorically with acquiring a certain property or attribute and thus achieving a purpose.

\section{The Causal Path Metaphor}

This metaphorical structure is the third major metaphor system for certain types of causation. More importantly, the Causal Path Metaphor plays an important role and can be even takenas a key role in certain types of causal explanation for human action. Without reservation, this metaphorical structure employs our common knowledge regarding motion through space to some destination.

Based on the findings, there are seven expressions considered as emotion metaphor at the location event-structure. The data will be analyzedas the following:

Take your first steps towardshappiness

In this metaphorical structure, we are now introduced to other ordinary emotion metaphors in our everyday discourse that will be important in the emotion concept reasoning, namely that of emotion as a destination. The semantics of towards has the literal meaning of a movement of our action to achieve something or to obtain our purpose which is near to us just before or around a certain place. From there, the writer argues that the expression in this data provides an underlying conceptual metaphor.

In this context, the term take step towards evokes the highly physical force which is being applied in a metaphorical manner to the abstract concept of happiness as a very common metaphor. Consequently, in the case of happiness, the writer argues that it should be transformed into metaphorical destination before we could arrive there. Since this use of happiness is commonly used in general discourse, the writer can argue that this physical aspect has an important part to play in the actual conceptualization of the concept of emotion resulting to make it likely that this linguistic metaphor stems from a conceptual metaphor which we might name HAPPINESS IS A PLACE conceptual metaphor.

More importantly, we need to keep in mind that this name on the conceptual metaphor is only a suggestion, and we must be aware of not overly simplifying a complex structure like a conceptual metaphor by putting too much weight on the names the writer gives it.

The expression above utilizes our common knowledge about motion through space to some destination. Accordingly, when it is extended into the concept of causal path metaphor, it will be perfectly conceptualized into a metaphorical entailment of a conceptual metaphor, which governs the submapping RESULT IN IS LEADING TO. Given the mapping of the concept "toward corresponds to leading to."

To illustrate,in the source domain of motions, the semantic feature of towards is part of the meaning of direction. It reveals getting closer to someone or something. From this point, it is obvious that "towards" 
will eventually result in a motion to naturally end up where that path leads someone or something, unless something intervenes. When metaphorically extended to the pattern of causal path metaphor in general, take your first step toward happiness entails motion through space to some destination of metaphorical result in happiness.

\section{Force Dynamics}

Metaphorical structures have an important role in the study of the conceptualization of emotion. The study of emotion concepts gives evidence strongly that emotions are characterized by a great deal of an overlapping set of metaphors. For this reason, it might be the case that there exists a master metaphor for the emotion.

Talmy's theory of Force Dynamics which explains and describes many aspect of language can be applied in the study of conceptual metaphor regarding the emotion corpus in this thesis. More importantly, in this metaphorical structure, there exists the most basic and skeletal emotion scenario in the folk theory of emotion. To illustrate, the scenario is the existence of a cause that induces a person (self) to have an emotion, and the emotion causes the person to produce some response.

His theory comprises mainly three skeletal emotion concepts, namely Emotion is an Opponent, Emotion is a Natural Force, and Emotion is a Physical Force.

\section{Emotion Is an Opponent}

This structural metaphor of emotion demonstrates the working of force dynamics in the conceptualization of emotions. The most basic in this concept is there are two opponents in the struggle: the force entities of agonist against the force entities of antagonist. In addition, there are two intrinsic force tendencies such as the force tendency toward action and the force tendency toward inaction. Consequently, this interaction of the force leads to the resultant of the action and inaction. On the whole, the balance of strengths will be the stronger entity and the weaker entity.

Based on the writer's findingin the corpora of emotion coming from BNC, there are eight expressions considered as emotion metaphor in which they are conceptualized as EMOTION IS AN OPPONENT conceptual metaphor. The data will be analyzedas the following:

You might have to face anger and disgust from your children

It is apparent to recognize the conceptual metaphor that has relationship with emotion concept in this sentence. Now let us take a look at what exactly is carried over to the concept of anger from the metaphorical entailment potential of the source. Based on those semantic features above, this expression reveals the struggle involving two opponents: opponent one and opponent two. The opponent that is inactive refers to agonist; meanwhile the opponent that is active refers to antagonist. Hence, the expression above is conceptualized by conventional conceptual metaphor EMOTION IS AN OPPONENT. Given the mapping "corresponding to opponent one in the source is you as the rational self in the target, meanwhile corresponding to opponent two in the source is an anger as the emotion in the target domain.

Accordingly, two potentials might be happening which result inan effect on them and change them in some way: the possibility of either opponent one winning or opponent two winning. Just in case the opponent one's force tendency wins, thus, the rational self's force tendency tries to maintain control over the emotion. Conversely, when the opponent two's force tendency wins, thus, the emotion's force tendency can cause the self to lose control. 
In line with the explanation above, the concept of anger from the expression in data D-1 is structured by the force-dynamic interpretation; as a result, it is categorized into THE EMOTION IS AN OPPONENT conceptual metaphor

\section{Emotion Is a Natural Force}

This metaphorical structure is the second major of the conceptual metaphor system for certain types of force dynamics. This structure conceptualizes emotion as a natural force in which it encapsulate the most people's belief concerning with emotion that people just as physical objects are powerless when they have to deal with with the powerful natural forces acting to them.

Based on the findingin the corpora of emotion coming from BNC, there are five expressions considered as emotion metaphor in which they are conceptualized as EMOTION IS AN OPPONENT conceptual metaphor. The data will be analyzedas the following:

You have been up and down on life's wave

The above concept of life has been attributed with a spatial term, mostly up or down. This use of spatial terms in relation to this conceptualization of emotion is common and widespread, both in the material and around us, by laymen as well as experts, that we will immediately suggest that we are dealing not only with a linguistic phenomenon, both with a conceptualization of the state of this concept in terms of spatial relation.

That we are dealing with conceptual metaphor can be further sustained by the use of up and down on wave, in which the spatial aspects used for envisaging the state this concept of emotion have been extended, and the up and down on wave now even has a three-dimensional space envisaged as surrounding them.

Based on the semantic features, it can thus be concluded respectively that up has the sense of a movement towards a higher position; similarly, moving into vertical position. Meanwhile, down has the definition of moving from above and onto a surface as well as moving towards the end or the lower part of the position. Similarly, it is a kind of movement that falls to the ground. On the other hand, wave is defined as a raised line of water which moves across the surface of an area of water, especially the sea. Equally, it is the slow up and down movement of the sea with large but smooth waves which is caused by the wind

Given the evidence of literal meanings, the writer suggests that the linguistic expression in this data emerges with underlying conceptual metaphors. In this definition then, life is being conceptualized as a wave. If life is conceptualized in any way as a kind of wave, we should be able to find evidence of the metaphors being applied to life. At this point, we see the quite clear physical term of wave which is moving up and down being applied in a metaphorical manner to the abstract concept of life, which is ordinary and widespread metaphor in daily discourse regarding to the natural phenomenon of life. If something has the ability to get movement, it needs a physical mass, and something that is abstract and does not have a physical manifestation would not be so likely to go through movement. For the same reason, the writer argues that such a physical aspect has an important role to play in the actual conceptualization of the concept of life.

On the whole, the writer suggests that this linguistic metaphor exists because we conceptualize life in a distinctly dichotomous manner: Life is something that can be moving upward, similarly, it can be 
moving downward. Therefore, there is no denying that the actions performed by this abstract concept form a consistent moral flavoring; that is, life is colorful which is envisaged as sometimes happy and sometimes sad as well as sometimes successful and sometimes unsuccessful.

Let us now take a look at what exactly is carried over to the force dynamics of emotional concept from the metaphorical entailment potential of the source of the expression above. This linguistic usage can be evidence for the exploitation of conceptual metaphor through some semantic features. Based on the explanations above, it must therefore be recognized that the expression reveals a conceptual metaphor which is conceptualized by NATURAL FORCE metaphor by which the semantics of sea clearly sustains this concept. More importantly, when that expression is applied to emotion, it gives rise to the underlying logic; namely, that there is an extremely forceful entity affecting a physical object and this object can do nothing. In other words, people are passive and helpless concerning with it.

To get into an in-depth comprehension, it is worth noticing the working of how force dynamic applies to them. When it is metaphorically extended into metaphorical force dynamics in general, there is physical object which is inactive and keep being the same. This is called the agonist. In this case, you as the subject is mapped into the metaphorical physical object. The other, natural force which is active and attempts to cause effect in physical object. This is the antagonist. In this sense, wave is mapped into metaphorical natural force. As a result, the physical object undergoes effect in a passive way.

In comparison, corresponding to physical object in the source is the rational self in the target, while corresponding to natural force in the source is the emotion in the target domain. Corresponding to physical object's force tendency in the source is the rational self's force tendency to continue to behave as before the emotion, and corresponding to natural force's tendency in the source is the emotion's force tendency to cause the self to respond to emotion. Summing up, "You have been up and down on life's wave" depicted this situation.

Given this explanation, the writer argues that the underlying conceptual metaphor that gives rise to the above linguistic metaphorical expression is the EMOTION IS AN OPPONENT conceptual metaphor. Therefore, the explanation above seems to be evidence whichindicates that this data of the research is categorized into EMOTION IS A NATURAL FORCE.

\section{Emotion Is a Physical Force}

The last metaphor of emotion that the writer uses to demonstrate the working of force dynamics in the conceptualization of emotions is the EMOTION IS A PHYSICAL FORCE conceptual metaphor. This metaphorical structure comprises mainly a variety of forms: MECHANICAL, ELECTRIC, GRAVITATIONAL, MAGNETIC. In order to be much clearer, they are envisaged such as EMOTION IS A PHYSICAL FORCE, EMOTION IS A MECHANICAL FORCE, EMOTIONAL EFFECT IS PHYSICAL CONTACT, and EMOTION IS A MAGNETIC FORCE

Based on the finding in the corpora of emotion coming from the BNC, there are twenty nine expressions considered as emotion metaphor in which they are conceptualized as EMOTION IS AN OPPONENT conceptual metaphor. The data will be analyzedas the following:

Johnny knew Fergie was in love with him 
In this example, the use of in may evoke a more physical image of the emotion concept actually being in the building. Here we are introduced to a very common metaphor, that of love conceptualization. This metaphor is much used to envisage mostly for those who are in a romantic couple, making it reasonable to suggest that it not only is a linguistic metaphor, but a conceptual metaphor, in which we conceptualize the emotion in terms of CONTAINERS.

The term in is literally defined as the exact position which is situated inside or towards the inside of a container, place or area, or surrounded or enclosed by something. Additionally, it is considered asexisting or happening inside a person, object, organization, place or country. On this basis, here we can see the meaning reflected in this linguistic expression, making it entailment of the specific conceptual metaphor.

The sense of the sentence above would thus be much in line with ontological metaphors, that is, ways of viewing emotions as entities and substances (Lakoff\& Johnson 1980). In this sense, emotions are in general viewed metaphorically as substances and therefore as containers. The term of in in this contexts seems to represent a more physical aspect, the readers almost get the feeling that the term love turn out to be some sort of room, space or particular place which can be entered by someone through/by the door. In other words, the love exists in space, and it has well-defined boundaries. For this reason, the writer views it as a CONTAINER OBJECT. To illustrate, people who partake in it is conceptualized as objects. Furthermore, events like the beginning they make relationship and finishes are metaphorical objects. Finally, the activity of their relationship is considered as a metaphorical substance.
Now notice this data is turnedinto the working of force dynamic by which this linguistic expression extended to this concept in general. In the source domain, there is a physical object with the force tendency toward inaction, namely, to keep remaining unaffected by force; particularly, continuing to keep stability as before. In this case, Fergieis mapped onto metaphorical physical object. Furthermore, there is also another force exerting entity here, that is, a physical force that has the force tendency to create some effect which resultsin the changing in the object. In this case, in love is mapped into metaphorical physical force. Consequently, the resultant action will be the object undergoing some effect. In other words, our metaphorical result in this phrase seems to express that Fergie has strong feelings of affection for another man and be romantically and sexually attracted to a man, or she feels great affection for a man in her life.

Accordingly, corresponding to physical object in the source is the self in the target, meanwhile corresponding to physical force in the source is the cause of emotion in the target domain. On the other hand, corresponding to physical object's force tendency in the source is the rational self that has the force tendency to stay as before, particularly, to be unemotional. Meanwhile, corresponding to the force tendency of physical force is the cause of emotion that has the force tendency to cause the self to become emotional. In this case, the situation of this concept is illustrated by the linguistic metaphorical expression above in which a cause of emotion acts on the rational self causing it to become emotional.

Given this finding, it can be inferred that the term of in love which makes up the above-mentioned metaphorical linguistic expression is taken as a realization of the various forms of EMOTION IS A PHYSICAL FORCE conceptual metaphor 
of force dynamics. In particular, the writer argues that it could be due to an underlying conceptual metaphor which is called EMOTION IS A MAGNETIC FORCE.

\section{CONCLUSION}

Based on the analysis and description of the data, some conclusions can be drawn. The conceptual metaphors used in expressing emotion are the causation concept - that of causation as a physical force, comprises the Location EventStructure Metaphor, the Object EventStructure Metaphor, the Causal Path Metaphor. The Location Event-Structure are the prominent conceptual metaphor involved an understanding of change of state as metaphorical motion from one location to another. The Object Event-Structure Metaphor are transfer of possession. The Causal Path Metaphor utilizes the motion through space to some destination. In addition, another conceptual metaphor is force dynamics comprising Emotion is an Opponent, Emotion is a Natural Force, and Emotion is a Physical Force. Emotion is an Opponent provides two opponents in struggle. Emotion is a Natural Force is an extremely forceful entity that affects a physical object to be passive and helpless. Emotion is a Physical Force conceptualizes emotion as the form of physical, electric, gravitational, magnetic force. An interesting finding concerning emotion was that the expression of emotion employed more conceptual metaphors. The writer found that the semantic features which are mostly used to envisage the figurative language of emotion concept were established by using personification, which is, treating something as if it were in the form of a human being.

\section{ACKNOWLEDGMENT}

I would like to thank Journal Bahasa $\&$ Sastra for publishing this research article.

\section{REFERENCES}

de Sousa, R.1987. The Rationality of Emotions. Cambridge, Mass \& London, England: MIT Press.

Gibbs, R.W.Jr.2008. Metaphor and Thought. Cambridge University Press

Goodman, N. 1976. Languages of Art: Second Edition. Indianapolis: Hackett

Kövesces, Z.2010. Metaphor: A Practical Introduction.New York 10016: Oxford University Press.

Lakoff, G and Johnson, M.1980. Metaphors We Live $B y$. The University of Chicago Press.

Snaevar, S. 1997. Metaphors, Narratives, Emotions: Their Interplay and Impact. Amsterdam - New York, NY 201

Sugiyono.2009. Memahami Penelitian Kualitatif. Bandung: Alfabeta. 